\title{
Correlational Study on the Contextual Factors Influencing The Effectiveness of Flexible Learning: The Case of One State University in the Philippines
}

\author{
Alberto D. Yazon1, Mario R. Briones' ${ }^{2}$ Eden C. Callo ${ }^{3}$ \\ 1, 2, 3 Laguna State Polytechnic University, Philippines
}

\begin{abstract}
With the onset of the pandemic, no face-to-face instruction is seemingly the most pressing problem faced today in schools. The acquisition of required skills has been challenged by the digital divide and limited access to quality and equitable higher education. This scenario has pushed LSPU for further flexibility in rendering its services anchored on its vision of becoming a center of technological innovation that promotes interdisciplinary learning, sustainable utilization of resources, collaboration, and partnership with the community and stakeholders. Hence, this quantitative, non-experimental research with an observational approach utilized predictive design explored the LSPU's delivery and assessment of flexible learning based on the outcomes-based education. The research instrument with an excellent reliability coefficient of .962 was programmed in the google form, and the extracted data from 5,314 respondents were analyzed using summary statistics and regression analysis. Multiple linear regression analysis was used to treat the data. It was found out that there is a great extent of implementation of sound assessment practices that support student learning. The respondents agreed that the level of teacher's assessment practices and support to student learning are promising and attuned to the requirements of flexible learning. The University's migration plan really worked for the faculty and students. The majority of the respondents are motivated and engaged in flexible learning. The study found that $55.1 \%$ variance in the effectiveness of the implementation of flexible learning is positively explained by teacher's assessment practices and support to students, student's attainment of cognitive learning outcomes, student's engagement and motivation, and student's self-assessed academic performance during the new normal.
\end{abstract}

Keywords: Flexible Learning, Learning Continuity Student Engagement Contextual Factors Learning Outcomes

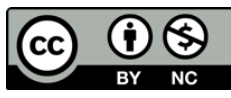

This is an open access article under the CC-BY-NC license.

\section{INTRODUCTION}

The worldwide Coronavirus pandemic and its suggestions are by a wide margin the best test approaching over humankind today. Its drastic effect on practically all parts of our lives has constrained us out of nowhere to retrofit our way of life, work, and relational relations. At the onset of the pandemic, the vast majority of the nation's chose to close their boundaries and eventually to likewise close schools and colleges. From that point forward, large numbers of them didn't get back to vis-à-vis classes; they actually worked in the online mode. If there should arise an occurrence of colleges, the suspension of "physical" instructing and the need to change to an online mode has been a significant test for advanced education organizations and their capacity to change rapidly to the new Coronavirus reality.

The abrupt change in the teaching and learning activities into virtual modalities was completed to proceed with the scholarly courses while keeping away from individuals gathering and the likely danger of the spread of contamination (Amir, Tanti, et al., 2020). Nonetheless, there is the vulnerability about what school terminations meant for student achievement, just as how the

Corresponding author

albertyazon@lspu.edu.ph; president_office@lspu.edu.ph; eden.callo@lspu.edu.ph

DOI: https://doi.org/10.31098/ijmesh.v4i2.671

Research Synergy Foundation 
International Journal of Management, Entrepreneurship, Social Science and Humanities (IJMESH), Vol. 4 (2), 146-156 Correlational Study on the Contextual Factors Influencing The Effectiveness of Flexible Learning: The Case of One State University in the Philippines Alberto D. Yazon, Mario R. Briones, Eden C. Callo

abrupt paradigm shift of instruction will keep on influencing student attainment of learning outcomes.

Lederman (2020) evenhandedly expressed that because of the Coronavirus emergency, educators and students both end up in the circumstance where they felt constrained to accept the flexible learning modalities as the best option for the continuity of learning. Thinking about the option of no face-to-face instruction during the pandemic, distance learning has been an important tool to sustain student cognitive and non-cognitive development during school closures. That being said, there are still concerns that online learning may have been the best substitute for face-to-face instruction, especially so in the absence of universal access to infrastructure (hardware and software) that support learning and lack of adequate preparation among teachers and students for the unique demands that distance learning pose (OECD, 2020).

The new arrangement for distance education, whether online or otherwise, requires teachers to quickly change their practices, including daily tasks, responsibilities, and responsibilities. During the COVID crisis, teachers may be required to develop new alternative and diverse methods to monitor student learning (from assessment to correction of learning losses), including formative and summative methods (International Fund United Nations Children's Emergency, 2020).

Each grade and subject area may require different methods for obtaining individual and collective feedback and support. Teachers may lack the relevant resources, training, and experience at home, especially on digital learning platforms. By focusing on student self-study, some courses can significantly reduce the time allotted to teachers to guide the learning process. Teachers may also find it difficult to assess students' learning levels to determine whether students are on the right track, as well as learning gaps or losses due to school closures and corrective measures. Such assessments are essential to provide information for the learning process and/or promotion, accreditation, and the student's access to higher education (UNICEF, 2020).

Under these premises, the work of the teacher as an educator, lecturer, and trainer must be able to influence their students. In this case, the teacher must be able to continuously improve their performance, which is the capital of educational success (Manik \& Bustomi, 2011). Efforts to improve teachers' teaching should encourage students to learn (Thoonen et al., 2011). Educational psychologists agree that classroom learning involves contextual factors, such as cognitive and emotional processes, and is strongly influenced by social processes. This means that students must be able and willing to regulate their cognition, motivation, and emotions and adapt to the social environment to promote their learning (Boekaerts, 2010).

In lieu of the aforementioned, the Laguna State Polytechnic University implements the Flexible Teaching and Learning Model. This Flexible Teaching and Learning Model is being operationalized in LSPU context with its desire to serve its purpose of providing quality and equitable education amidst the challenging time.

The BOR-approved LSPU Learning Continuity Plan sets the direction of LSPU in the opening of classes this First Semester AY 2020 - 2021. The faculty and students are well-informed and welltaken care of by the top management. The strong administrative support and full cooperation of the entire academic community make the implementation of flexible learning at LSPU possible. One - hundred percent of the faculty members developed a self-paced learning module and were able to successfully and effectively navigate the google classroom to support their synchronous and asynchronous classes.

However, there are still students who don't have the means to embrace the online delivery model because of poor internet connectivity and lack of gadgets (laptop or desktop). Classes are limited 
International Journal of Management, Entrepreneurship, Social Science and Humanities (IJMESH), Vol. 4 (2), 146-156 Correlational Study on the Contextual Factors Influencing The Effectiveness of Flexible Learning: The Case of One State University in the Philippines Alberto D. Yazon, Mario R. Briones, Eden C. Callo

to theoretical/conceptual skills development, and the preparation, review, and monitoring of the self-paced learning module require enough time to accomplish. These limitations challenged the academic community, especially the learners' achievement and attitude towards learning. The existence of contextual factors that affect learning outcomes can be studied internally or externally. The most important internal and external factors and tools that affect the process and outcomes of student learning are interest, motivation, and teachers (Aritonang, 2008). The solution that can be provided is to improve the learning results of the class and to be able to compete by applying learning models supported by interesting learning media (Kusuma, Wijayati, and Wibowo, 2008)

Hence, this study explores the influence of contextual factors such as teacher's assessment practices, student's acquisition of learning outcomes, motivation, engagement on the effectiveness of the implementation of flexible learning. Studying and understanding these factors allow refinement of programs, better communications, and better engagement, interest, and motivation among students. Further, the findings of the study will be an input to academic rules and policies in the new normal in LSPU's Learning Continuity and Contingency Plans as a response to the unprecedented effect of the COVID-19 in the educational sector. A module or primer for a bridge program is desired to be developed to sustain students' cognitive and affective well-being, allowing them to actively participate in a distance learning environment.

\section{Problem Statement and Research Questions}

The purpose of this study is to evaluate the influence of the contextual factors on the delivery and assessment of LSPU in the flexible learning aspects of outcomes-based education. It also further defines and quantifies the achievement of the ideals and the most important learning outcomes for each course or subject in the plan in the first semester of 2020-2021.

Specifically, it sought answers to the following questions:

1. What is the level of teacher's assessment practices and support to student learning as perceived by the students?

2. What is the level of students' attainment of cognitive learning outcomes?

3. What is the level of engagement and motivation of students in a flexible learning environment?

4. What is the level of students' self-assessed rating based on your experiences in their synchronous/asynchronous/modular classes?

5. What is the level of effectiveness of LSPU's flexible learning implementation as rated by the students?

6. Do the level of teacher's assessment practices and student support, student's attainment of cognitive learning outcomes, level of engagement and motivation, selfassessed rating based on their experiences in their synchronous/asynchronous/modular classes significantly predict the effectiveness of LSPU's flexible learning implementation?

\section{RESEARCH METHODS}

Quantitative methods, that is, non-experimental research using observation methods and predictive design were used because it involves a systematic investigation of the nature of relationships or the associations between variables, rather than direct causality (Lodico, 2006). This design is used to check whether changes in one or more variables (for example, contextual factors) are related to changes in other variables (for example, effectiveness of flexible learning). 
International Journal of Management, Entrepreneurship, Social Science and Humanities (IJMESH), Vol. 4 (2), 146-156 Correlational Study on the Contextual Factors Influencing The Effectiveness of Flexible Learning: The Case of One State University in the Philippines Alberto D. Yazon, Mario R. Briones, Eden C. Callo

It is carried out on four (4) campuses of Laguna State Polytechnic University. The questionnaire was published, privately messaged, and emailed to target respondents. They were asked to describe their personal characteristics in terms of age, gender, campus, college, and grade. Out of 22,000 students, 5,314 responded voluntarily.

The majority of respondents were from the San Pablo City campus ( $=2,509 ; 47 \%)$. There were 1,501 (28\%) respondents from the main Santa Cruz campus, 812 (15\%) from the Los Banos campus, $434(8 \%)$ from the Siniloan campus, and $58(2 \%)$ from the satellite campus. They involve agriculture, arts and sciences, business management and accounting, computer science research, criminal justice education, engineering, industrial technology, food nutrition and nutrition, hotel management and tourism, industrial technology, nursing and related health, and teacher training programs. At the high school level $(\mathrm{N}=354 ; 7 \%)$, higher education $(\mathrm{N}=4,512 ; 85 \%)$ and postgraduate level $(\mathrm{N}=448 ; 8 \%)$.

Eighty-seven percent are 16 - 23 years old, $11 \%$ are $24-39$, while $2 \%$ belong to the age bracket of 40 - 55 years old. The majority of the respondents are millennials and only a few generations $\mathrm{X}$ and Y. Out of 5,314 total respondents, 3,458 (65\%) are female, $1786(34 \%)$ are female, while 70 (1\%) preferred not to indicate their gender.

They are also asked to respond to the Likert-type scale questions covered in the study. The online survey tools were validated by experts in educational management, quality assurance, statistics, and research. The verified questionnaire has obtained a very good reliability factor of .932 . The final device has been scheduled for Google Form, and the extracted data were analyzed using the appropriate tool.

The number of frequencies and percentages have been used to describe the respondent's profile. Mean, and standard deviation have been utilized to assess their mean assessment on the parameters measured. The data shows an approximately normal distribution based on the Smirnov-Kolmogorov normality test ( $p>.05$ ). Multiple linear regressions have been adopted to evaluate effective predictors in the effective implementation of flexible learning.

\section{RESULTS AND DISCUSSION \\ On Teacher's Assessment Practices}

Table 1. Level of Teacher's Assessment Practices and Support to Student Learning as Perceived by the Students

\begin{tabular}{|c|c|c|c|c|c|}
\hline Indicative Statement & Mean & SD & Sk & $\begin{array}{c}\text { Scaled } \\
\text { Response/ } \\
\text { Description }\end{array}$ & Rank \\
\hline $\begin{array}{l}\text { 1. My output is collected or reviewed in any } \\
\text { form. }\end{array}$ & 4.94 & 0.98 & $\begin{array}{c}- \\
0.77\end{array}$ & Agree & 3 \\
\hline $\begin{array}{l}\text { 2. There are class meetings and or regular } \\
\text { interactions (virtual or by group } \\
\text { chat/email) in our class. }\end{array}$ & 5.13 & 0.98 & $\overline{-} 17$ & Agree & 1 \\
\hline $\begin{array}{l}\text { 3. There are tools and support to share } \\
\text { effectively the recommendations and } \\
\text { feedback of my teachers for my work } \\
\text { done or submitted. }\end{array}$ & 4.86 & 1.07 & $\overline{-} \cdot \overline{8}$ & Agree & 4 \\
\hline $\begin{array}{l}\text { 4. My teachers use a mechanism to ensure } \\
\text { the credibility and integrity of formative }\end{array}$ & 4.96 & 0.99 & $\overline{0} \overline{9}$ & Agree & 2 \\
\hline & & & & & $149 \mid$ \\
\hline
\end{tabular}


and summative assessments assigned to

me.

5. Teachers give additional support to students that have fallen furthest behind, including those from poor families 4.83 1.14 0.98 Agree 5 without access to technology.

\begin{tabular}{ccccl}
\hline \hline Overall & 4.94 & 0.85 & $\begin{array}{c}- \\
0.87\end{array}$ & High Extent \\
\hline
\end{tabular}

Legend:

Scaled Response Descriptive Interpretation

5.50 - 6.00 - Strongly Agree

4.50 - 5.49 - Agree

Great Extent

3.50 - 4.49 - Moderately Agree

2.50 - 3.49 - Slightly Disagree

1.50 - 2.49 - Disagree

High Extent

1.00 - 1.49 - Strongly Disagree

Least Extent

Moderate Extent

Less Extent

Not at All

Table 1 shows the level of teacher's assessment practices and supports to student learning as perceived by the students. Generally, there is a great extent of implementation of sound assessment practices that support student learning. The respondents agreed that there are class meetings and or regular interactions (virtual or by group chat/email) in class ( $\bar{x}=5.13$ ). In fact, teachers explored various learning portals such as google classroom, Moodle cloud application, Edmodo, Facebook classroom, messenger, e-mail, among others, to facilitate the course efficiently.

Apparently, teachers use a mechanism to ensure the credibility and integrity of formative and summative assessments assigned to students $(\bar{x}=4.96)$, the output is collected or reviewed in any form $(\bar{x}=4.94)$, and there are tools and support to share effectively the recommendations and feedback of my teachers for my work done or submitted $(\bar{x}=4.86)$. As observed, the honesty form and non-disclosure agreement are filled out by students every time they are given assessment tasks. Moreover, students at all levels are also reminded to follow the course policies in the course guide and syllabus, which includes the authenticity of their outputs. Prompt feedback is also given to students to ensure that their works are valued, recognized, properly accounted for, documented, and assessed for continual improvement.

In the same vein, teachers give additional support to students that have fallen furthest behind, including those from poor families without access to technology $(\bar{x}=4.86)$. The University exercises its utmost leniency and consideration for student welfare. For the full extent of understanding and leniency, faculty members are not allowed to conduct classes that are not on approved students' official schedule of classes, nor discipline their students by reducing the grades by being late attending the synchronous classes or non-opening of their video/camera. This humanitarian consideration is hoped to provide equity despite of the digital divide due to limited access to technology.

The small standard deviation values and negative skewness coefficients clearly indicate that the respondents have almost the same level of agreement on the items asked, which are generally above the reported mean score. They agreed that the level of teacher's assessment practices and support to student learning are promising and attuned to the requirements of flexible learning. 
On Student's Attainment of Learning Outcomes

Table 2. Level of Student's Attainment of Cognitive Learning Outcomes

\begin{tabular}{|c|c|c|c|c|c|}
\hline Indicative Statement & Mean & SD & Sk & $\begin{array}{c}\text { Scaled } \\
\text { Response/ } \\
\text { Descriptio } \\
\mathrm{n}\end{array}$ & $\begin{array}{c}\text { Ran } \\
\mathrm{k}\end{array}$ \\
\hline $\begin{array}{l}\text { 1. I understood and learned the } \\
\text { essential learning competencies } \\
\text { reflected in the course guide or course } \\
\text { syllabus. }\end{array}$ & 4.78 & 1.01 & $\begin{array}{c}- \\
0.68\end{array}$ & Agree & 1 \\
\hline $\begin{array}{l}\text { 2. The desired learning outcomes for } \\
\text { this semester were met. }\end{array}$ & 4.68 & 1.09 & $\begin{array}{c}- \\
0.73 \\
\end{array}$ & Agree & 2 \\
\hline Overall & 4.73 & 0.98 & $\begin{array}{c}- \\
0.68\end{array}$ & $\begin{array}{l}\text { High } \\
\text { Extent }\end{array}$ & \\
\hline \multicolumn{6}{|l|}{ Legend: } \\
\hline \begin{tabular}{lr}
\multicolumn{1}{c}{ Scaled Response } & Des \\
5.50-6.00-Strongly Agree & Gre \\
$4.50-5.49-$ Agree & Hig \\
$3.50-4.49-$ Moderately Agree & Moc \\
2.50-3.49-Slightly Disagree & Les \\
$1.50-2.49-$ Disagree & Least Exten \\
$1.00-1.49-$ Strongly Disagree & Not
\end{tabular} & $\begin{array}{l}\text { iptive In } \\
\text { Extent } \\
\text { Extent } \\
\text { rate Ext } \\
\text { xtent } \\
\text { All }\end{array}$ & preta & & & \\
\hline
\end{tabular}

This evaluation result affirms that the University's migration plan really worked for the faculty and students. While faculty are expected to be proactive and reflective in their teaching practice in face-to-face settings, it is really challenging for them to migrate to the new teaching and learning environment. Critical to the approaches is the provision of an opportunity to explore the potentialities of e-learning by establishing a complete migration learning plan, designing and developing an e-learning module from the migration plan template, and translating the e-learning module to the LSPU platform.

The identification of essential Intended Learning Outcomes (ILOs) propels the faculty to prioritize what should be taught and learned in a flexible learning environment. Classifying the High Essential (HE), Moderately Essential (ME), or Least Essential (LE) streamlines what content must be covered in the entire semester. It gives direction as to what teaching-learning activities and assessment strategies should be selected to make learning more meaningful, engaging, and relevant.

Since the attainment of the intended learning outcomes optimizes the capacity of the institution to deliver quality education to students, it is noteworthy that it becomes possible because of the strong support system from the administration. The top management has been very supportive in the academic undertakings of the University, including capacity-building both for faculty and students. The synergy between and among teaching and non-teaching staff complements the readiness and preparedness of the academic community in adopting and implementing flexible learning. 
International Journal of Management, Entrepreneurship, Social Science and Humanities (IJMESH), Vol. 4 (2), 146-156 Correlational Study on the Contextual Factors Influencing The Effectiveness of Flexible Learning: The Case of One State University in the Philippines Alberto D. Yazon, Mario R. Briones, Eden C. Callo

On Student's Level of Engagement and Motivation

Table 3. Cross Tabulation of the Respondent's Level of Engagement and Motivation to Learn amidst the Pandemic

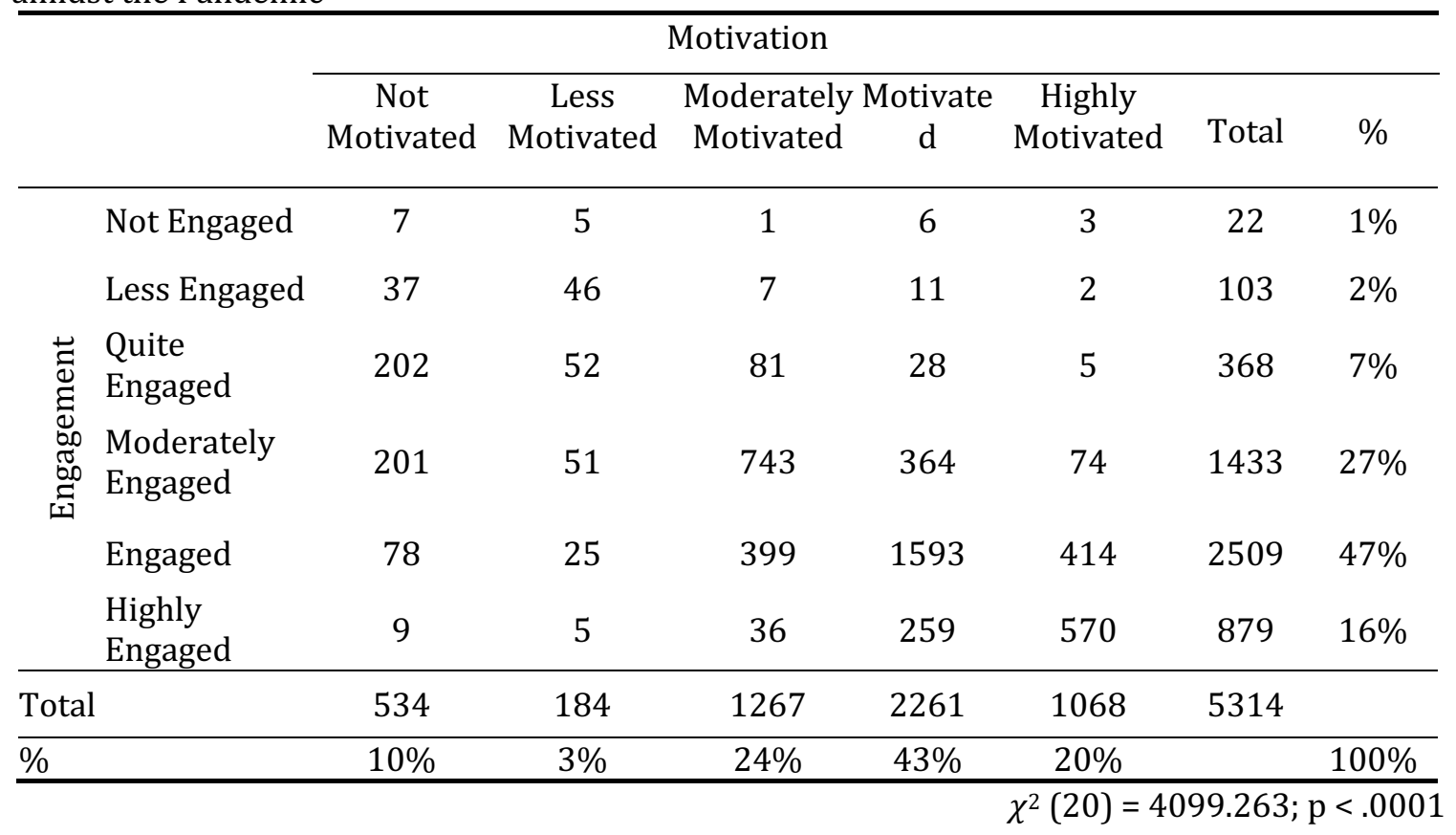

As shown in Table 3,13\% are less motivated, among which $10 \%$ are quite engaged. However, $83 \%$ are motivated, while $90 \%$ are committed to flexible learning. Online learning improves the awareness of students in distance learning. The interaction between students and teachers consisting of temporary opportunities in the campus classroom is available for review and reflection and is recorded for them. When they react during the teaching, they also have the opportunity to review and understand the lesson.

The chi-square test of independence analysis revealed that student engagement and level of motivation are significantly related $\left[\chi^{2}(20)=4099.263 ; p<.0001\right]$. This result suggests that flexible learning can be both engaging and motivating. When students study online, they can also experience occasional moments when the possibilities of the medium and the course goals are suddenly combined. Students capture that moment and shape it to encourage and enrich their learning. If properly designed, online education can be as effective as face-to-face teaching, emphasizing the design of the learning experience, content quality, and student engagement (Callo and Yazon, 2020). 


\section{On Self-assessed Student Performance and Effectiveness of Flexible Learning}

Table 4. Cross Tabulation of the Respondent's Level of Self-Assessed Performance and Perceived Effectiveness of the Implementation of Flexible Learning

\begin{tabular}{|c|c|c|c|c|c|c|c|c|c|}
\hline & & \multicolumn{6}{|c|}{ Implementation } & & \multirow{2}{*}{$\begin{array}{c}\text { Total } \\
\%\end{array}$} \\
\hline & & Poor & $\begin{array}{c}\text { Needs } \\
\text { Improve } \\
\text { ment }\end{array}$ & $\begin{array}{c}\text { Fairly } \\
\text { Satisfacto } \\
\text { ry } \\
\end{array}$ & $\begin{array}{c}\text { Satisfac } \\
\text { tory }\end{array}$ & $\begin{array}{c}\text { Very } \\
\text { Satisfacto } \\
\text { ry }\end{array}$ & $\begin{array}{c}\text { Outstan } \\
\text { ding }\end{array}$ & & \\
\hline \multirow{8}{*}{$\frac{0}{\frac{\pi}{0}}$} & $\begin{array}{l}\text { Poor } \\
\text { Needs }\end{array}$ & 6 & 5 & 1 & 3 & 1 & 0 & 16 & $0.3 \%$ \\
\hline & $\begin{array}{c}\text { Improvemen } \\
\mathrm{t}\end{array}$ & 2 & 17 & 20 & 9 & 1 & 0 & 49 & $0.9 \%$ \\
\hline & $\begin{array}{c}\text { Fairly } \\
\text { Satisfactory }\end{array}$ & 4 & 34 & 147 & 143 & 31 & 5 & 364 & $6.8 \%$ \\
\hline & Satisfactory & 3 & 29 & 164 & 1351 & 624 & 100 & 2271 & $43 \%$ \\
\hline & $\begin{array}{c}\text { Very } \\
\text { Satisfactory }\end{array}$ & 4 & 15 & 42 & 391 & 1361 & 359 & 2172 & $41 \%$ \\
\hline & Outstanding & 1 & 3 & 6 & 38 & 91 & 303 & 442 & $8 \%$ \\
\hline & Total & 20 & 103 & 380 & 1935 & 2109 & 767 & 5314 & \\
\hline & $\%$ & $1 \%$ & $2 \%$ & $7 \%$ & $36 \%$ & $40 \%$ & $14 \%$ & & $100 \%$ \\
\hline
\end{tabular}

The results in Table 4 revealed that in terms of self-assessed performance, $92 \%$ reported that their semestral rating could range from satisfactory (85\% - 89\%) to outstanding (95\% - 100\%). The respondents are seemingly confident that they can perform satisfactorily despite the challenges brought by the pandemic. They see a greater opportunity to learn, as reflected in their self-assessed rating.

Good teaching in flexible learning is to allow most students to use the necessary cognitive process level to achieve the expected results of more academic students' spontaneous use. In addition, effective teaching and learning in today's universities emphasize three points: the level of student participation related to the level of learning activities required to achieve the expected learning outcomes (from "description" to "theorization"), and related activities that may be stimulated by the learning level teaching method, and the academic orientation of students (Biggs \& Tang, 2011).

In terms of the perceived effectiveness of the implementation of flexible learning, $90 \%$ of the respondents appraised a satisfactory to outstanding rating. Considering this result, it can be inferred that the LSPU Flexible Learning is grounded to the needs of the students. It responds to its main goal, which is to provide learners with maximum flexibility in terms of learning content, timetables, interviews, and innovation evaluation.

Teachers' knowledge and self-efficacy on the use of social media, mobile phones, and other digital tools, including well-designed printed learning modules, offer various opportunities to make learning accessible to all learners. Being adaptive to the current situation and the resourcefulness to adopt the new ways of teaching and assessing students' learning are desirable teachers' desirable traits in this challenging time (Yazon and Callo, 2021). 
International Journal of Management, Entrepreneurship, Social Science and Humanities (IJMESH), Vol. 4 (2), 146-156

Correlational Study on the Contextual Factors Influencing The Effectiveness of Flexible Learning: The Case of One State University in the Philippines

Alberto D. Yazon, Mario R. Briones, Eden C. Callo

\section{On the Test of Significant Prediction}

Table 5. Test of Significant Prediction of Teacher's Assessment and Support to Students, Student's Attainment of Cognitive Learning Outcomes, Level of Engagement and Motivation, and Student Grade on the Effectiveness of the Implementation of Flexible Learning

\begin{tabular}{|c|c|c|c|c|c|}
\hline \multirow{2}{*}{ Predictors } & \multicolumn{2}{|c|}{ Unstandardized Coefficients } & \multirow{2}{*}{$\begin{array}{c}\text { Standardized } \\
\text { Coefficients }\end{array}$} & \multirow{2}{*}{$\mathrm{t}$} & \multirow[b]{2}{*}{ Sig. } \\
\hline & $\mathrm{B}$ & Std. Error & & & \\
\hline (Constant) & 0.277 & 0.062 & & 4.492 & 0.000 \\
\hline $\begin{array}{l}\text { Assessment Practices and } \\
\text { Support to Students }\end{array}$ & 0.177 & 0.014 & 0.165 & 12.483 & 0.000 \\
\hline $\begin{array}{l}\text { Attainment of Learning } \\
\text { Outcome }\end{array}$ & 0.199 & 0.014 & 0.213 & 14.446 & 0.000 \\
\hline Engagement & 0.051 & 0.012 & 0.051 & 4.073 & 0.000 \\
\hline Motivation & 0.127 & 0.008 & 0.199 & 15.879 & 0.000 \\
\hline Student Grade & 0.371 & 0.012 & 0.325 & 29.713 & 0.000 \\
\hline
\end{tabular}

Adj. $R^{2}=55.10 \%$

Dependent Variable: Effectiveness of Flexible Learning

$F(5,5308)=1307.034 ; p<.001 ; N=5,314$

Regression Equation: $E F L=.177 A P+.199 A L O+.051 E+.127 M+.371 S G$ where

$E F L=$ Predicted Effectiveness of Flexible Learning Scores

$A P=$ Assessment Practices; $A L O=$ Attainment of Learning Outcomes

$E=$ Engagement $\boldsymbol{M}=$ Motivation; $S G=$ Student Grade

Multiple linear regression was performed to determine the significant predictors of the effective implementation of flexible learning. As shown in Table 6, a significant regression equation was found $(F(5,5308)=1307.034, p<.001)$, with an $R^{2}=$ of .743 . The predicted effectiveness of the implementation of flexible learning (EFL) is equal to:

\footnotetext{
where

EFL $=$ Predicted Effectiveness of Flexible Learning Scores

$\mathrm{AP}=$ Assessment Practices and Support to Students;

ALO = Attainment of Learning Outcomes

$\mathrm{E}=$ Engagement;

$\mathrm{M}=$ Motivation;

$\mathrm{SG}=$ Student Grade
}$$
\mathrm{EFL}=.277+.177 \mathrm{AP}+.199 \mathrm{ALO}+.051 \mathrm{E}+.127 \mathrm{M}+.371 \mathrm{SG}
$$

The model further revealed that $55.1 \%$ variance in the effectiveness of the implementation of flexible learning is positively explained by teacher's assessment practices and support to students $(\beta=.165)$, student's attainment of cognitive learning outcomes $(\beta=.213)$, student's engagement $(\beta=.051)$ and motivation $(\beta=.199)$ and student's self-assessed academic performance during the new normal $(\beta=.325)$.

\section{CONCLUSION AND RECOMMENDATIONS}

The COVID19 pandemic has added flexibility in several areas. Institutions, administrative structures, courses, and learning strategies and methods become flexible and easy to adapt. 
International Journal of Management, Entrepreneurship, Social Science and Humanities (IJMESH), Vol. 4 (2), 146-156 Correlational Study on the Contextual Factors Influencing The Effectiveness of Flexible Learning: The Case of One State University in the Philippines Alberto D. Yazon, Mario R. Briones, Eden C. Callo

Flexibility is of special significance and has become the core of university reform: 1) Focus on greater accessibility: Universities must be flexible enough to attract and recruit more new student groups; 2) Focus on individual students so that they can learn when they want it, what they want, and the way they want it.

Shifting the focus from teachers to students is believed to help meet these needs, thereby improving teaching for a wider range of students. Specifically, defining the learning outcomes that students should achieve should reflect the topics that teachers should teach.

Recognizes that good teaching is a function of the quality management system and human resources of the entire organization, so it is necessary to develop policies and procedures that encourage the entire organization to perform good teaching and evaluation. LSPU must continue to exercise academic judgment/freedom by implementing available flexible learning and other alternative delivery models to replace face-to-face learning models on campus. The discretion of the university and its faculty must be reasonable, transparent, and verified based on the results.

In addition, university officials can establish a monitoring mechanism to improve the quality of flexible learning, respond to student needs, and the huge loss of academic performance after returning to school. Mechanisms to quantify, limit, and estimate the scope, acquisition, and use of distance education materials can be explored. This will allow the people who implement the plan and their target customers (students) to improve the plan, better communication, and better participation, interest, and motivation.

\section{REFERENCES}

Amir, L.R., Tanti, I., Maharani, D.A. et al. Student perspective of classroom and distance

learning during COVID-19 pandemic in the undergraduate dental study program Universitas Indonesia. BMC Med Educ 20, 392 (2020). https://doi.org/10.1186/s12909-02002312-0

Aritonang, K. T. (2008). Interest and motivation in improving student learning outcomes. Journal of Sower Education, 7(10), 11-21.

Boekaerts, M. (2010). Motivation and self-regulation: Two close friends. In T. C. Urdan, \& S. A. Karabenick (Eds.), The decade ahead: Applications and contexts of motivation and achievement (pp. 69-108). Emerald Group Publishing Limited.

Callo, C. and Yazon, A. (2020). Exploring the Factors Influencing the Readiness of Faculty and Students on Online Teaching and Learning as an Alternative Delivery Mode for the New Normal. Universal Journal of Educational Research, 8(8), 3509 - 3518. DOI: 10.13189/ujer.2020.080826.

Danili, E., \& Reid, N. (2006). Cognitive factors can potentially affect pupils' test performance. Chemistry Education Research and Practice, 7, 64-83.

DQ Institute, 2019. DQ Institute (2019). Outsmart the Cyber-pandemic: Empower every child with digital intelligence by 2020. Retrieved from file:///D:/COVID/DQEveryChild\%20DQ\%20Institute.html.

EdSource. (2020). Coronavirus: Highlighting strategies for student success. Retrieved fromhttps://edsource.org/topic/coronavirus.

Few, A. L. (2007). Integrating Black consciousness and critical race feminism into family studies research. Journal of Family Issues, 8(4), 452-473 
International Journal of Management, Entrepreneurship, Social Science and Humanities (IJMESH), Vol. 4 (2), 146-156

Correlational Study on the Contextual Factors Influencing The Effectiveness of Flexible Learning: The Case of One State University in the Philippines

Alberto D. Yazon, Mario R. Briones, Eden C. Callo

Garrison, D. R., Anderson, T., \& Archer, W. (1999). Critical inquiry in a text-based environment: Computer conferencing in higher education. The Internet and Higher Education, 2(2), 87105.

Hooks, b. (1984). Feminist theory from margin to center. Boston, MA: South End Press

Journal of Chemical Education Innovation, 2(1). Lodico, N., Spaulding, D., \&Voegtle, K. (2006). Methods of Educational Research. John Wiley \& Sons, Inc

Kusuma, E., Wijayati, N., \& Wibowo, L. S. (2008). SAVI-based NHT type cooperative learning to improve chemistry learning outcomes of the subject of reaction rates.

Kusuma, E., Wijayati, N., \& Wibowo, L. S. (2008). SAVI-based NHT type cooperative learning to improve chemistry learning outcomes of the subject of reaction rates. Journal of Chemical Education Innovation, 2(1).

Lederman, D. (2020))(March 18,. Will shift to remote teaching be boon or bane for inline learning? Inside Higher $\quad$ Ed. $\quad$ Retrieved from file://D:/COVID/Most\%20teaching\%20is\%20going\%20remote.\%20Will\%20that\%2 0help\%20or\%20hurt\%20online\%20learning.html.

OECD (2020). Strengthening online learning when schools are closed: The role of families and teachers in supporting students during the COVID-19 crisis. http://www.oecd.org/coronavirus/policy-responses/strengthening-online-learningwhen-schools-are-closed-the-role-of-families-and-teachers-in-supporting-studentsduring-the-covid-19-crisis-c4ecba6c/

Polidore, E. (2004). The teaching experiences of Lucille Bradley, Maudester Hicks, and Algeno McPherson before, during, and after desegregation in the rural south: A theoretical model of adult resilience among three African American female educators (Doctoral dissertation, Sam Houston State University, 2004). Dissertation Abstracts International, $65,(08), 2924 \mathrm{~A}$

Russell, D. W., Russell, C. A., Chen, H. Y., Cacioppo, S., \& Cacioppo, J. T. (2019). To what extent is psychological resilience protective or ameliorative: Exploring the effects of deployment on the mental health of combat medics. Psychological Services. Advance online publication. https://doi.org/10.1037/ser0000343

Thoonen, E. E., Sleegers, P. J., Oort, F. J., Peetsma, T. T., \& Geijsel, F. P. (2011). How to improve teaching practices: The role of teacher motivation, organizational factors, and leadership practices. Educational administration quarterly, 47(3), 496-536. https://doi.org/10.1177/0013161X11400185.

United Nations International Children's Emergency Fund (UNICEF), 2020. Guidance: Assessing And Monitoring Learning During The Covid-19 Crisis. https://reliefweb.int/sites/reliefweb.int/files/resources/learning_assessments_durin g_covid-19_final.pdf

Yazon, A. and Callo, C. (2021). Assessing Teacher's Knowledge, Self-efficacy, and Practices (KSP) in Adopting Flexible Learning during the Covid-19 Pandemic. Universal Journal of Educational Research, 9(1), 136 - 144. DOI: 10.13189/ujer.2021.090115. 